\title{
Modern innovative and unconventional methods to combat soil erosion
}

\author{
Eleonora Tsoraeva ${ }^{*}$, Polina Alborova ${ }^{2}$, Liana Bazaeva $^{2}$, Dzerassa Khanaeva $^{2}$, and \\ Batrbek Kozyrev ${ }^{3}$ \\ ${ }^{1}$ I.T. Trubilin Kuban State Agrarian University, Kalinin str., 13, 350044, Krasnodar, Russia \\ ${ }^{2}$ Gorsky State Agrarian University, Kirova str., 37, 362040 Vladikavkaz, Russia \\ ${ }^{3}$ St. Petersburg State University of Aerospace Instrumentation, Bolshaya Morskaya str., 67, 190000 \\ St. Petersburg, Russia
}

\begin{abstract}
One of the reasons for the decline in agricultural land is soil degradation processes. The main negative processes occurring in soils and leading to their degradation are erosion (water and wind) and a decrease in the humus content in the soil. A significant spread of negative processes developing as a result of the action of natural and anthropogenic factors leads to a critical decrease in soil fertility. The washout of the upper fertile soil layer and the formation of large gullies due to improper soil treatment results in soil erosion. In order to prevent soil erosion, it is necessary to take measures to prevent an increase in the area of degraded land. The paper discusses modern innovative methods of combating water and wind soil erosion. Various examples of the application of modern innovative methods in different countries are presented.
\end{abstract}

\section{Introduction}

Rational and efficient use of the main means of agricultural production - agricultural land is an important factor in ensuring the food security of the Russian Federation. According to the Doctrine of Food Security of the Russian Federation, one of the main provisions of the National Security Strategy of the Russian Federation, the national interests of the state are to restore and increase the fertility of agricultural land, prevent the reduction of agricultural land, rational use of such land, protection and preservation of agricultural land from water and wind erosion and desertification [1].

However, the Doctrine reflects the risks that the country may face in its implementation. One of which is an increase in the share of degraded lands and a decrease in the fertility of agricultural lands due to their irrational use in agriculture. In this regard, one of the main lines of state policy in the field of food security is the restoration and improvement of the fertility of agricultural land, rational use of agricultural land, compliance with agricultural production technologies, as well as the development of land reclamation for agricultural land by maintaining the reclamation complex located in state property of the Russian Federation.

* Corresponding author: elionora@list.ru 


\section{Results and discussion}

One of the reasons for the decline in agricultural land is soil degradation processes. The main negative processes occurring in soils and leading to their degradation are erosion (water and wind) and a decrease in the humus content in the soil. A significant spread of negative processes developing as a result of the action of natural and anthropogenic factors leads to a critical decrease in soil fertility. The washout of the upper fertile soil layer and the formation of large gullies due to improper soil treatment results in soil erosion. In order to prevent soil erosion, it is necessary to cultivate the soil and sow crops across the slope.

Soil erosion control is a set of measures aimed at preventing water and wind erosion in agriculture during land development. Effective soil erosion control measures: water erosion is managed by controlling runoff and wind erosion by reducing wind speed and protecting soil from deflation. These are important methods of preventing water pollution, soil loss, wildlife habitat loss, financial loss and loss of human property.

Erosion control is used in agricultural land and natural areas in urban environments. Often a set of measures is required to protect fields from erosion.

In urban and road construction, soil erosion control measures are part of stormwater management and slope anchorage programs.

Erosion controls often involve creating physical barriers, such as vegetation or rock terraces, to erosion-causing factors in order to absorb some of the erosion-causing wind or water energy. Erosion control measures also include the construction and maintenance of drainage systems in the fields and the construction of storm drains. They are often used in conjunction with soil sediment control systems, such as sedimentation tanks and silt fences and storages.

The loss of some of the fields that are located on the banks of rivers and ravines is often observed. Erosion of river banks and ravines is a natural process. However, land management schemes that alter hydrography and/or vegetation cover can increase or decrease the rate of migration of the riverbed or reduce the expansion of ravine boundaries. In many places, regardless of whether the banks are unstable due to human activity, people try to keep the river in one place or prevent the ravine from expanding. This can be done to restore the environment or to prevent the river from altering the course of the fields with agricultural crops used by people. One way to do this is to lay masonry or gabions along the shore.

To prevent the expansion of ravines, planting of shrubs, trees, strengthening of slopes and other methods are usually used. Such plantings are most effective, since trees and shrubs keep the soil from being washed away by their roots.

The most common soil erosion control methods are:

- conservation farming - reducing the use of plowing and tillage systems, in which no plant residues remain on the soil surface, rejection of clean fallow.

- planning of the landscape, roads, dams and territories into symmetrical square sectors. This method is widely used in the USA and Canada. 


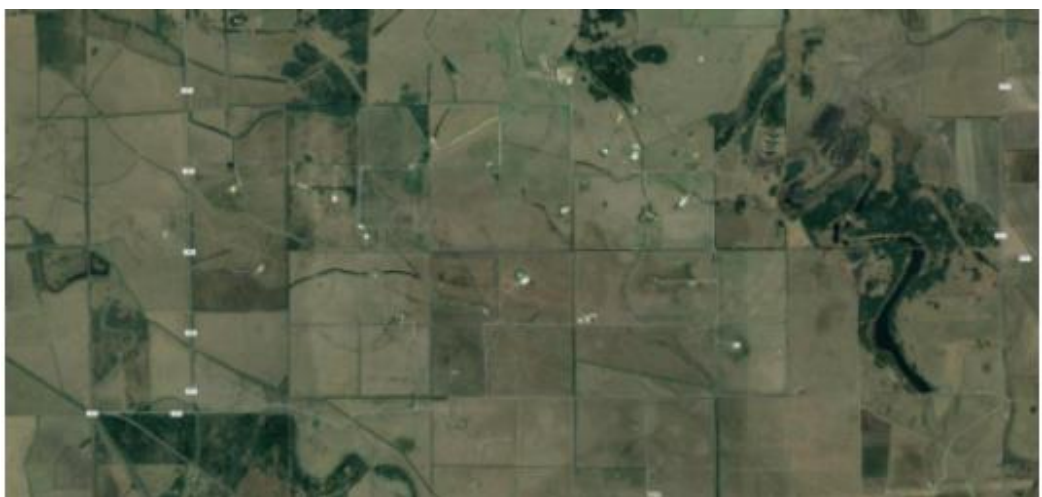

Fig. 1. Landscape planning for preventing soil erosion.

- irrigation systems that prevent drip soil erosion and soil washout - underground drip irrigation.

- constant tramline - agricultural machinery management system, which is used to reduce soil damage caused by heavy machinery or repeated passes of agricultural machinery on the field. With this system, all agricultural machinery passes across the field only along permanent technological lines.

- drainage systems - they are of various designs and allow draining excess water from the field, and this is one of the methods of combating soil erosion.

- perennial plantations - vineyards, berry plantations and orchards. Perennial plantations are designed across the slope to limit water flow and prevent soil erosion. Applied in the Russian Federation, Asia.

- cage drainage localization systems - geogrids. Cage systems made from straw, twigs, reeds and other vegetation are used in China to anchor dune slopes and prevent sand from drifting into fields and expanding deserts. This system helps to protect the slopes from wind drift and anchoring plants in these places.

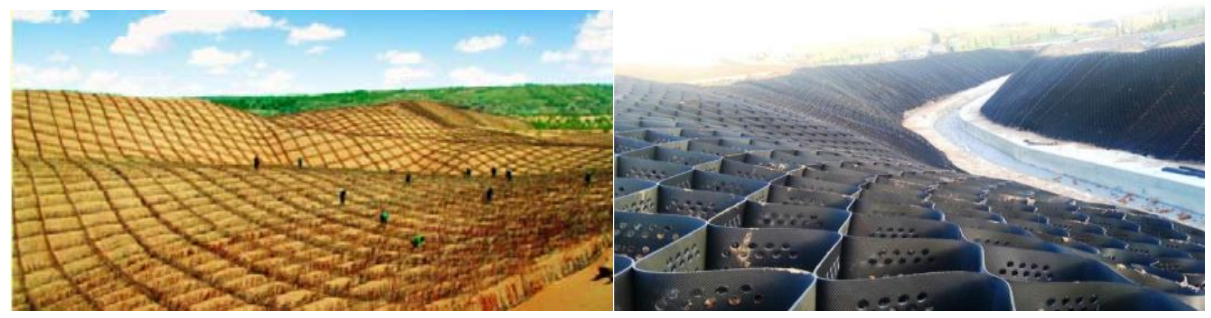

a)

b)

Fig. 2. Cage drainage localization systems. a) - from straw, twigs and other vegetation b) geogrids.

- designing soil-protective crop rotations is an effective method of combating erosion and degradation of the soil cover, since crop rotation and tillage methods affect crop residues and other factors important to the soil.

- soil crevice is one of the most effective methods of combating soil erosion, and it is one of the most effective solutions for the accumulation of moisture in the soil. These techniques are very effective in combating soil erosion and allow the accumulation of moisture in the soil due to the destruction of soil compaction.

- conservation / soil protection tillage - strip tillage is used, one of the most modern and effective methods of soil protection from erosion, increasing the accumulation of moisture in winter due to snow retention, increasing the humus content in the soil and soil fertility. 
- contour embankments and plantations - using this method, embankments-barriers of stones and trees are created along the edges of fields, where there is a risk of erosion.

Contour farming - contour plowing / contour tillage and contour seeding. In contour tillage, the soil is cultivated along the contour lines, across the slopes, and this prevents soil erosion. Contour sowing allows getting a harvest of field and fodder crops, where previously it was impossible to do this. Farming, carried out along the contour geolines across the slopes, prevents soil erosion. This kind of farming requires modern approaches and special equipment, it goes well with CTF technology.

- fibrous rolls, they are also called straw grids - covering the slopes with special rolls of plant fiber, makes it possible to plant plants and prevent soil erosion.

- gabions - structures made of stones and nets that allow fixing slopes or make terraces, while water can seep through the stones into the soil. Gabions help to strengthen slopes and problem areas in order to prevent soil erosion. It is also possible to plant plants in between.

- hydroseeding - helps to sow grass slopes and prevent soil erosion. Widespread in Australia.

- level distributors - hydraulic structures of various types that allow cutting the water flow and distributing it over the surface or absorbing it due to the combination with drainage systems to prevent the formation of gullies and ravines after heavy rains.

- mulching is covering the soil surface with a layer of material to prevent erosion, preserve soil moisture, improve soil fertility and health, reduce weed growth and improve the appearance of the area. Organic plant residues are commonly, but not exclusively, used for mulch. It can be permanent (for example, plastic film) or temporary (for example, chopped straw).

- sowing of perennial crops - if the field is covered with vegetation for several seasons, then soil erosion will decrease.

- the use of plastic coatings and materials in agriculture. Plastics or the use of polymers to coat soil and plants helps protect against erosion. The polymeric materials themselves are often called agrofibre. Various films and agrofibers designed to cover plants/soil are used to protect against erosion. Such coverings range from plastic sheeting for mulching, row coverings, high and low tunnels to polymer greenhouses.

- polyacrylamide (as a coagulant) - in modern conditions, this method is not widely used in the open field. This drug is introduced into the soil, which absorbs moisture and slowly gives it back to the plants. This improves the quality of the soil and protects against soil erosion.

- fire fighting - prohibition of burning stubble and bushes in the fields. It is prohibited to burn stubble, bush and dry grass on pastures - this contributes to soil erosion and leads to a whole range of negative consequences.

- placement of buffer zones - an area with vegetation (buffer strip) near water bodies or on the border of fields and ravines, which helps to protect soils from erosion and water bodies from pollution. The creation of protective buffers keeps the soil from erosion and washout, but this is a very time-consuming and costly work. Their purpose is to slow down the flow of water and allow it to be absorbed into the soil, since plants can only use rainfall when it is available as soil moisture. This type of erosion protection is commonly used in the USA and Australia.

- stone embankments, masonry and ramparts of stones and concrete - used to protect against soil erosion during melt water runoff, erosion of the coastline, to protect coastal structures, dams, irrigation structures, roads, buildings, fields and plantations on the slopes of river channels, supports, foundations and other structures from erosion.

- Strip farming technology - sowing of various crops in strips is used on slopes and is combined with contour farming, or when there is no alternative method of preventing soil erosion. Usially strip crops alternate forage grasses for hay, wheat or other forage with 
strips of row crops, such as corn, soybeans, servants or sugar beets. Forage crops are mainly used as cover crops. Sometimes, on especially eroded fields, permanent strips of perennial plantations are used. But on most fields, all stripes alternate annually. Strip farming is the cultivation of crops in long, narrow strips in the same field, the next year the arrangement of crops changes according to the crop rotation.

- sand barriers / sand catchers. Sand barriers are created to force wind-blown sand to accumulate in a desired location, similar to snow retention barriers. Sand barriers are used to control erosion, stabilize sand dunes, prevent sand from entering fields, buildings and roads, and to keep young stands from being drifted by sand in desert regions. This method is used in Japan.

- bioswale - covering the banks of the water stream with vegetation. Bioswales are canals covered with vegetation, designed for the concentration and drainage of storm water. Bioswales can also be useful for replenishing groundwater.

- terracing - the creation of terraces on the slopes allows protecting the soil from erosion, fixing the plants on the slopes and protecting them from being washed away by streams of water. For example, stone terraces on banana plantations in southern Turkey are a reliable method to protect the soil from erosion and ensure stable yields over the years.

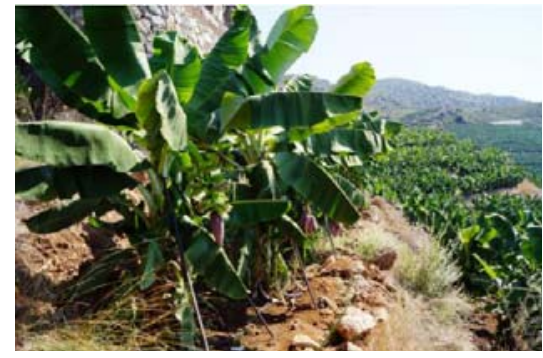

Fig. 3. An example of a stone terrace on a banana plantation in southern Turkey.

- windbreaking forest belts - it has been proven that forest belts improve the microclimate, contribute to a significant increase in productivity and protect the soil from erosion. On average, properly designed protective forest belts increase the yield in the field by $20-27 \%$.

- restriction of zoogenic erosion - regulation of the number of sheep, goats and cows in pastures. The fight against zoogenic soil erosion consists in limiting the number of animals and limiting grazing, as well as in the transition from grazing to fattening on farms. Uzbekistan.

- snow retention - stubble left in the field is the best method of snow retention and soil erosion control.

- backfilling of gullies and field planning with the help of graders and special machines. Coping with the effects of soil erosion is very costly and demanding.

\section{Conclusion}

Thus, erosion processes in the form of water and wind erosion on all agricultural lands have a significant negative impact on the ecological and economic situation of each economic entity, significantly reduce soil fertility, which certainly requires comprehensive measures to protect land resources from the effects of water and wind erosion. Nowadays, there are many modern innovative methods of soil erosion control. All these measures should be developed in the process of drawing up master plans for the use of the land area, land management projects and intensive land management, as well as various projects for the protection of both land resources and the overall natural environment of a particular region 
or specific territory. Therefore, taking into account the above, it is necessary to take good care of land resources and actively use methods to combat soil erosion.

\section{References}

1. Decree of the President of the Russian Federation of January 21, 2020 No. 20 "On the approval of the Doctrine of food security of the Russian Federation"//

https://www.garant.ru/products/ipo/prime/doc/73338425/

2. E. Tsoraeva, A. Bekmurzov, S. Kozyrev, A. Khoziev, A. Kozyrev, Web of Conferences 215, 02003 (2020) https://doi.org/10.1051/e3sconf/202021502003

3. E. Tsoraeva, S. Mezhyan, M. Kataeva, L. Hugaeva, T. Rogova, E3S Web of Conferences 224, 03001 (2020) https://doi.org/10.1051/e3sconf/202022403001

4. B. Kozyrev, E. Tsoraeva, Al-Azawi Nagam, A. Chibirova, A. Kozyrev, E3S Web of Conferences 244, 03018 (2021) https://doi.org/10.1051/e3sconf/202124403018

5. E.N. Tsoraeva, R.K. Gadzhiev, S.E. Kuchiev, A.A. Pekh, S.A. Mezhyan, IOP Conf. Series: Materials Science and Engineering 1083, 012052 (2021) https://doi:10.1088/1757-899X/1083/1/012052

6. A. Zaitseva, E3S Web of Conferences 244, 03017 (2021) https://doi.org/10.1051/e3sconf/202124403017

7. S. Ovchinnikova, M. Kalinichenko, N. Markina, E. Schneider, E3S Web of Conferences, 157, 06028 (2020) https://doi.org/10.1051/e3sconf/202015706028

8. S.A. Bekuzarova, S.S. Basiev, A.Kh. Kozyrev, T.A. Dulaev, V.I. Buyankin, Journal of Pharmaceutical Sciences and Research, 10, 4, 893-895 (2018)

9. E.N. Stratinskaya, et al., Scientific journal of the Russian Research Institute of Melioration Problems 1 (1), 7 (2011)

10. E.N. Stratinskaya, T.P. Andreeva, Melioration and water management 2, 33-35 (2010)

11. E.N. Tsoraeva, Problems of rational use and protection of soils, In the collection: Results of research work for 2017, a collection of articles based on the materials of the 73rd scientific and practical conference of teachers (2018)

12. V.D. Zhukov, E.N. Tsoraeva, A.U. Perov, IOP Conf. Series: Earth and Environmental Science 650, 012028 (2021) https://doi:10.1088/1755-1315/650/1/012028

13. S. Ovchinnikova, A. Borovkov, G. Kukinova, N. Markina, E3S Web Conf., 244, 01007 (2021) DOI: https://doi.org/10.1051/e3sconf/202124401007

14. S. Ovchinnikova, A. Borovkov, E. Schneider, A. Kalinichenko, E3S Web Conf. 244, 01013 (2021) DOI: https://doi.org/10.1051/e3sconf/202124401013

15. S.V. Ovchinnikova, E.M. Schneider, G.V. Kukinova, IOP Conf. Series: Materials Science and Engineering 1083, 012045 (2021) DOI: https://doi.org/10.1088/1757899X/1083/1/012045

16. S.V. Ovchinnikova, A.Yu. Kalinichenko, A.A. Lyamina, E.M. Schneider, IOP Conf. Series: Materials Science and Engineering, 1083, 012051 (2021) DOI: https://doi.org/10.1088/1757-899X/1083/1/012051 